Valóságos könyvtár - könyvtári valóság. Könyvtár- és információtudományi tanulmányok 2020. Szerk. Kiszl Péter, Boda Gáborné Köntös Nelli.

Budapest, ELTE BTK Könyvtár- és Információtudományi Intézet. 2021. 393-402.

\title{
SZEMÉLYES DIGITÁLIS HAGYATÉKOK MEGŐRZÉSE
}

\author{
NAGY ANDOR \\ OSZK KI Kutatási és Elemző Osztály, kutató könyvtáros; \\ PTE Humán Fejlesztési és Művelődéstudományi Intézet Könyvtár- és \\ Információtudományi Tanszék, egyetemi tanársegéd
}

\section{TARTALMI ÖSSZEFOGLALÓ}

Az első digitális számítógépek megjelenése óta az információelóállítás módja az élet egyre több területén változik meg, és az információhordozó már csak ritkán analóg. A papíron elóállított szöveget felváltotta a digitális szöveg, a képet már nem filmtekercsre rögzítjük, hanem bitekben tároljuk és sok esetben hivatalos vagy magánjellegú ügyeinket is az interneten keresztül, a digitális térben intézzük el. A folyamat eredménye, hogy a személyes hagyaték, amely egy ember élete során keletkezik, egyre inkább függ a számítógépek, elektronikus adattárolók élettartamától és megbízhatóságától. Ráadásul, a webes szolgáltatások és a felhőtechnológia elterjedése révén az előállított adathoz való hozzáférés módja sok esetben nem egzakt és nem helyhez kötött, emiatt teljes körű feltárása rendkívül nehéz. Ez azt a veszélyt hordozza magában, hogy az elektronikusan, az utódok számára sok esetben ismeretlen webcímeken tárolt személyes hagyatékok jóval hiányosabbak lesznek, mint az analóg információhordozók korában. A probléma kezelésére tucatnyi online szolgáltatást indítottak az elmúlt évtizedben, ám ezek egy jelentős része megszűnt vagy nem kellóen megbízható ahhoz, hogy legféltettebb adatainkat is a szolgáltatóra bízzuk. Tanulmányunkban azzal a kérdéssel foglalkozunk, hogy lehetséges-e kellő biztonsággal, egy életen át megőrizni digitális adatainkat, és lehet-e partner ebben a folyamatban a könyvtár.

\section{Bevezetés}

Ahogy egyre több, korábban fizikai formában létező tárgyi emlék válik digitális tartalommá (pl. levelezések, fényképek, gyűjtemények), úgy nő az igény arra, hogy ezeket valahogy megőrizzük családunk, ismerőseink számára. A feladat nehéz, hiszen jelenleg nem ismerünk olyan adattárolási megoldást, amely korlátlan ideig, vagy legalább egy emberi élet során biztonsággal képes megőrizni a digitális adatokat. Adatvesztéssel életük során a legtöbben találkoznak, néha olyan adat veszik el, amely könnyedén pótolható, néha olyan, amely kisebb személyes tragédiával ér fel.

Egyre több olyan webes szolgáltatás létezik, amely digitális hagyatékok kezelésével foglalkozik. Egy részük búcsúüzenetek halál utáni elküldését vállalja e-mailben, vagy a közösségi médián keresztül, mások emlékweboldalak készítésére alkalmasak, és egyre több az olyan szolgáltatás is, amelyek személyes digitális tartalmak (pl. fényképek, 


\section{NAGY ANDOR}

felhasználói fiókok jelszavai, előfizetések adatai, végrendelet stb.) tárolását vállalják, a felhasználó halálát követően pedig átadják azokat a megjelölt személyeknek.

A téma szakértőinek és érdekeltjeinek körében olyannyira népszerü terület a digitális hagyatékok kezelése, hogy 2015-ben James Norris, a University College London munkatársa és a DeadSocial.org létrehozója megalapította a Digitális Örökség Sžövetséget (Digital Legacy Association). A szervezet célja többek között: felhívni a figyelmet a digitális örökségek kezelésének fontosságára, részt venni a brit törvényalkotásban, eszközöket és segédleteket létrehozni a digitális hagyatékok kezelésének megkönnyítésére, képzéseket és konferenciákat tartani stb. Éves konferenciájuk a Digitális Örökség Konferencia (Digital Legacy Conference), amelyet minden évben máshol rendeznek meg.

Összehasonlítva a fizikai formában létező tárgyi emlékekkel, a digitális hagyaték jóval sérülékenyebb, és ha valaki nem gondoskodik megőrzésérôl még életében, örököseinek talán felbecsülhetetlen értékekről kell lemondaniuk.

\section{Szakirodalmi áttekintés}

Az elmúlt tíz évben sorra jelentek meg a digitális hagyatékkal, azon belül is a személyes digitális hagyatékok kezelésével foglalkozó szakkönyvek és tanulmányok. A téma szakértőinek munkáit talán a legátfogóbban Donald T. Hawkins foglalta össze az általa szerkesztett kötetben. ${ }^{1}$ A szerzők a személyes digitális hagyatékok archiválásának fontossága mellett érvelnek, és a szakszerű archiválás technikai megvalósításának módjára vonatkozó hasznos tanácsokkal is ellátják az olvasót.

Ugyancsak értékes mű a személyes digitális hagyatékok kezelésének vonatkozásában Brianna H. Marshall szerkesztett kötete. ${ }^{2}$ A könyv négy főfejezetből áll. Az első fejezet gyakorlati segítséget nyújt a különféle platformokon létrejövő digitális tartalmak archiválásához. A második fejezet esettanulmányok formájában olyan közkönyvtári projekteket mutat be, amelyek célja a személyes digitális tartalmak összegyújtése, megőrzése és hozzáférhetővé tétele az olvasók bevonására építve. A harmadik fejezet olyan könyvtári együttműködések esettanulmányait tartalmazza, amelyek során a könyvtárak személyes digitális adatokat használtak fel a tájékoztatás vagy a tudományos munka során. Az utolsó fejezet esszéi pedig tulajdonjogi, adatvédelmi és etikai szemszögből vizsgálják a személyes digitális archiválást. A kötet megjelentetését az Amerikai Könyvtárak Szövetsége (American Library Association - ALA) támogatta, amely jelzésértékűnek vehető, és arra enged következtetni, hogy a könyvtáros szakma kezdi felismerni, hogy a könyvtárnak nemcsak lehetősége, de talán feladata is a személyes digitális hagyatékok gondozásának felvállalása. Szintén könyvtári vonatkozással bíró mű a Libraries Unlimited kiadványa, ${ }^{3}$ amelyben Stacy T. Kowalczyle, a Dominikánus Egyetem (Illinois) docense erősen technológiai vonatkozásban ír a hosszú távú, biztonságos adattárolás gyakorlatáról. 


\section{A digitális hagyaték fogalma}

Digitális hagyatéknak tekinthetünk minden olyan digitális formában létező adatot, amelynek létrejötte egy adott személyhez köthető. Egy részét azok az elektronikus felhasználói fiókok, jelszavak, hardvereken vagy távoli szerveren tárolt adatok teszik ki, amelyekhez valamilyen pénzforgalmi érték kötődik. A legkönnyebben értelmezhetők ezek közül a különféle pénzügyi szolgáltatások (pl. PayPal, TransferWise, Revolut), a webes szolgáltatóknál regisztrált felhasználói fiókok és előfizetések (pl. Netflix, Spotify, Deezer), illetve egyre inkább a számítógépes játékokhoz kötődő online fiókok.

A digitális hagyatékok másik részét azok a felhasználói fiókok, jelszavak, hardvereken vagy távoli szerveren tárolt adatok teszik ki, amelyekhez ugyan nem kötődik pénzforgalmi érték, így esetleges elvesztésük esetén anyagi kárral az örökösök sem szembesülnek, ám mégis értékkel bírnak, legyen az eszmei (pl. egy családi fénykép), tudományos (pl. egy be nem fejezett publikáció), gyakorlati (pl. névjegyzék) vagy bármilyen más, ami miatt érdemes megőrizni.

Érdekes jelenség, hogy a digitális hagyatékok egyre nagyobb részben technológiai vállalatok/vállalkozások kezében vannak. Ezekre (pl. Google, Facebook, YouTube) sok esetben hajlamosak vagyunk úgy tekinteni, mint amelyek örökre létezni fognak, miközben alig néhány éves szolgáltatásokról beszélhetünk, a Facebook is csak 2004-ben indult el, de globális elterjedése ennél is későbbre tehető.

\section{A digitális hagyatékok kezelésének nehézségei}

Egy ember biológiai halálával nem ér véget digitális élete. A hátrahagyott felhasználói fiókjai, előfizetései gazdátlanul tovább élnek, és a legtöbb nem örökíthető át úgy, mint az ingatlanok és ingóságok (pl. lakás, autó, karóra). A hagyatéki eljárás során ez utóbbiak láthatók, és törvényes módon örökíthetők. A személyes digitális hagyatékot szinte lehetetlen teljesen feltárni, ha annak láthatóságáról az elhunyt nem gondoskodott még életében. A közelmúltban a törvényhozók is felismerték, hogy szükség van valamiféle szabályozásra, iránymutatásra, ezért már megjelentek az első olyan kormányzati jogszabályok és ajánlások, amelyek a digitális hagyatékok kezelésével foglalkoznak.

A másik probléma, hogy sok, a webes szolgáltatások használatára vonatkozó felhasználási feltétel nem tér ki arra, hogy mi történik az adott profillal, előfizetéssel a kezelő halálát követően. Sőt, vannak, amelyek rögzítik, hogy a fiók nem átruházható és nem örökíthető.

A digitális hagyatékok esetében gondot jelent az is, hogy nehéz a tulajdonviszonyok egyértelmú azonosítása, hiszen a digitális térben a legtöbbször nincs szükség valós személyazonosság megadására. 


\section{NAGY ANDOR}

\section{A digitálishagyaték-kęelés mint iparág}

Egyre többen felismerik, hogy valamit tennünk kell digitális hagyatékunk megőrzésének érdekében, és ebben a felismerésben néhányan üzleti lehetőséget látnak. Az ötlet nem teljesen újkeletű, vagyonkezeléssel régóta foglalkoznak vállalatok/vállalkozások, de a digitális hagyatékok kezelése egészen más kompetenciákat, technikai feltételeket igényel. Az úgynevezett bizalmi vagyonkezelés (trust) intézménye az angolszász jogrendszerben már régóta létezik, de ezt az egyes országok kisebb-nagyobb módosításokkal vették át. A lényege, hogy a megbízó a vagyonát vagy annak egy részét ideiglenes jelleggel átruházza a bizalmi vagyonkezelőre.

A digitális örökség kezelésével foglalkozó vállalatok/vállalkozások hasonlóan múködnek, a digitális adatok tulajdonosa részben vagy egészben a hagyatékkezelőre bízza digitális adatait, jelszavait, vagy az olyan, előre megírt üzeneteit, amelyeket halála esetén szeretteinek, ismerőseinek kíván eljuttatni. Az első ilyen online szolgáltatás a FinalThoughts.com, amelyet Michael Krim hozott létre, miután átélt egy erős szélörvényt az Atlanti-óceán fölött egy Londonból Los Angelesbe tartó repülőgépjáraton. A megrázkódtatás után döbbent rá arra, hogy az ember élete bármikor alakulhat úgy, hogy búcsúzás nélkül kell távoznia. A FinalThoughts.com oldalon e-mail üzeneteket rögzíthetünk, amelyeket a rendszer halálunk után küld el az előre megadott e-mail-címekre.

A következőkben a teljesség igénye nélkül olyan szolgáltatásokat tekintünk át, amelyek a digitális hagyatékok részének vagy egészének online kezelésére szolgálnak.

\section{Jelszókeezeló szolgáltatások}

Ismerőseik telefonszámát az újtípusú kommunikációs csatornák elterjedése óta egyre kevesebben jegyzik meg, viszont megjegyzendő jelszavakból egyre több van. Azok a szolgáltatások is a webre költöztek, amelyekről ebben a formában korábban csak a tudományos-fantasztikus irodalom tett említést.

Ebből a problémából kiindulva indultak útjukra a jelszókezelő szolgáltatások. Ilyennel a legtöbben valószínúleg már találkoztak, hiszen a legnépszerűbb webböngészők (Chrome, Safari, Firefox, Edge) kivétel nélkül képesek a felhasználói jelszavak távoli szerveren tárolására, és azok szinkronizálására a felhasználó különböző eszközei között (pl. laptop és okostelefon).

\section{Szolgáltatásokéletvégi tervezéshez.}

A jelszókezelő szolgáltatások ugyan alkalmasak arra, hogy jelszavainkat ne csupán életünkben, de halálunk után is biztonságban tudhassuk, és örököseink számára is megőrizzük, ezek többsége nem célzottan azért jött létre, hogy gondoskodhassunk személyes digitális hagyatékunkról, hanem a mindennapos online bejelentkezéseink megkönnyítésére. Ezzel szemben sok olyan szolgáltatás létezik, amelyek kifejezetten az életünk utáni tervezést teszik lehetővé. A következőkben ezekre a szolgáltatásokra adunk példákat 
(1. táblázat). A táblázat hagyaték nevű oszlopának valamely sorába akkor illesztettünk pluszjelet, ha az adott szolgáltatás digitális hagyatékunk átfogó kezelésére szolgál, például megőrzi a feltöltött képeinket, jelszavainkat, végrendeletünket stb. Az üzenet nevű oszlop megfelelő sorában elhelyezett pluszjel arra utal, hogy az adott szolgáltatás még életünkben megírt és megcímzett halál utáni üzenetek elküldésére alkalmas.

\section{1. táblázat}

Nébány digitálishagyaték-kęelō szolgáltatás

\begin{tabular}{llccc} 
Név & URL & hagyaték & üzenet & emlék \\
\hline Afternote (2013) & afternote.com & + & & \\
\hline AfterVault (2016) & aftervault.com & + & + & \\
\hline Chronicle of Life (2008) & chronicleoflife.com & & & + \\
\hline Dead Social (2012) & deadsocial.org & + & & \\
\hline Everplans (2013) & everplans.com & + & & \\
\hline GoneNotGone (2016) & gonenotgone.com & & + & \\
\hline Leg8cy (2016) & leg8cy.com & & + & + \\
\hline Legacy (1999) & legacy.com & & & + \\
\hline Meminto (2017) & meminto.com & + & + & \\
\hline My Wonderful Life (2010) & mywonderfullife.com & + & + & + \\
\hline MyGoodbyeMessage (2013) & mygoodbyemessage.com & & + & \\
\hline PartingWishes (2000) & partingwishes.com & + & + & + \\
\hline Postumo (2017) & postumo.info & & + & \\
\hline SafeBeyond (2014) & safebeyond.com & + & + & \\
\hline SayGoodbye (2017) & saygoodbye.co & & + & \\
\hline Tributize (2017) & tributize.com & & & + \\
\hline WishesKeeper (2017) & wisheskeeper.com & + & & + \\
& & & + & + \\
\hline
\end{tabular}

A digitálishagyaték-kezelő szolgáltatások egyik jó példája a Chronicles of Life nevű szolgáltatás (https://www.chronicleoflife.com). Különlegessége abban rejlik, hogy olyan digitális objektumtárról van szó, amely saját bevallása szerint eleget tesz a megbízható digitális adattár (Trustworthy Digital Repository = TDR) kritériumainak, és ezzel valószínúleg egyedül van a piacon. A TDR fő célja a digitális tartalom nagyon hosszú távú megőrzése, ennek részleteiről a tanulmány egy későbbi fejezetében írunk. A weboldalra képek, szövegek és más, multimédiás tartalmak helyezhetők el. 


\section{NAGY ANDOR}

\section{Megbízható digitális adattár}

Mivel a legtöbb hagyatékkezelő szolgáltatás mindössze néhány éves, felmerülhet a kérdés, hogy vajon nagyobb biztonságban vannak-e digitális adataink ezeknél a szolgáltatóknál, mintha saját számítógépünkön vagy egy külső adattárolón tárolnánk azokat. Egyes szolgáltatások ismertsége és hosszú ideje tartó működése némi garanciát nyújt a megbízhatóságra és a hosszú távú múködésre, de vajon azt is garantálni tudják-e, hogy egy egész életen át megőrzik a pótolhatatlan, személyes adatokat?

A digitális adatok valóban hosszú távú tárolása évtizedek óta megoldandó probléma, és ennek kapcsán több irányelvet és szabványt is kidolgoztak. Ezek közül talán a legfontosabb a megbízható digitális adattár megléte. Első, átfogó definícióját az OCLC (Online Számitógépes Könyvtári Központ = Online Computer Library Centre) és az amerikai Kutatókönyvtárak Szövetsége (Research Libraries Group = RLG) közös jelentése tartalmazza: „A megbirható digitális adattár feladata, hogy megbizható, hosszú távú hozzáférést biztositson az adattárboz a kijelölt közösség számára most és a jövóben is." („A trusted digital repository is one whose mission is to provide reliable, long-term access to managed digital resources to its designated community, now and in the future.") 4 2007-ben a Kutatókönyvtárak Központjában (Center for Research Libraries = CRL), Chicagóban négy adatmegőrzéssel foglalkozó szervezet (The Digital Curation Center, Digital Preservation Europe, NESTOR és a Center for Research Libraries) tartott megbeszélést, amelynek során meghatározták a digitális archívumok tíz alapvető kritériumát. ${ }^{5}$

\section{A könyvtár lehetösége a digitálishagyaték-kezelésben}

A Kongresszusi Könyvtár és más könyvtári szervezetek már az ezredforduló előtt felismerték, hogy a digitális hagyatékok kezelésében a könyvtárnak szerepet kell vállalnia. 1998-ban a Kongresszusi Könyvtár létrehozott egy munkacsoportot, amelynek feladata egy átfogó digitalizálási stratégia kidolgozása volt. Két évvel később a Kongresszus 100 millió dollár támogatást ítélt meg a könyvtárnak ahhoz, hogy elindíthassa a Nemzeti Digitális Információs Infrastruktúra és Megörzés Programot (National Digital Information Infrastructure and Preservation Program = NDIIPP), a digitális információforrások megőrzése érdekében. ${ }^{6}$ A Kongresszusi Könyvtár 2010-ben létrehozta a Nemzeti Digitális Kuratórium Egyesülést (National Digital Stewardship Alliance = NDSA), amelyhez számos intézmény (egyetemek, vállalatok, kormányhivatalok) csatlakozott, közös céljuk pedig a digitális tartalmak megőrzésére vonatkozó szabványok és irányelvek megfogalmazása.

A könyvtár olyan intézmény, amelynek nagy gyakorlata van az adatok hosszú távú megőrzésében, ezért képesnek tartjuk arra, hogy olyan digitális adattárolókat építsen fel és kezeljen, amelyek megfelelnek az ISO 16363:2012,7 és ahhoz kapcsolódó szabványok valamennyi elvárásának. A szabvány olyan komplex feltételrendszert (szervezeti, személyzeti és finanszírozási feltételek) állít a megbízható digitális adattárat üzemeltetők elé, 
amelynek csak kevesen tudnak megfelelni, a nagyobb könyvtárak (és főként a nemzeti könyvtárak) viszont képesek lennének rá. Ráadásul olyan intézményrendszerről van szó, amely nem piaci alapon mûködik, hanem a legtöbb országban törvény írja elő a fenntartását. A személyes digitális hagyatékok könyvtári gondozásának lehetőségét és működését az 1. ábra segítségével szemléltetjük:

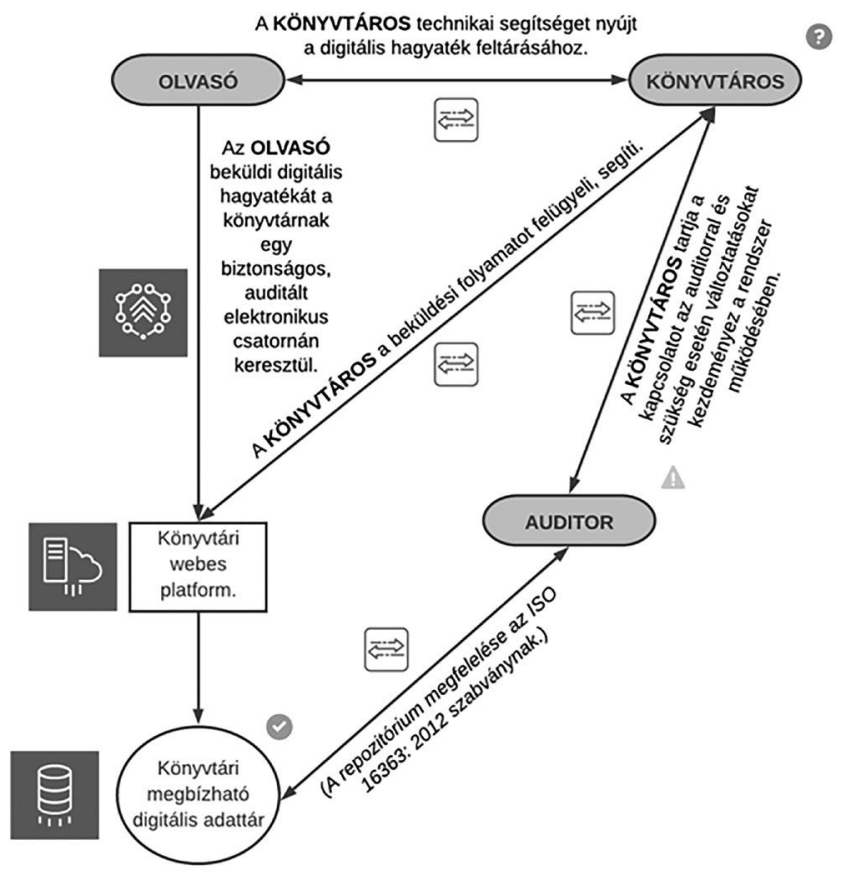

1. ábra: A személyes digitális hagyatékok könyvtári gondozásának lehetséges modellje

A digitális hagyatékok könyvtári gondozásának négy főszereplője van: az olvasó, a könyvtáros, az informatikai háttér és az auditor, aki igazolja, hogy a rendszer a szabványoknak megfelelően, biztonságosan és fenntarthatóan múködik. A folyamatban a könyvtárosoknak egyfajta támogató szerep jutna, ők segítenék a felhasználókat digitális hagyatékuk feltárásában, azoknak a pontoknak az azonosításában, ahol a digitális hagyatékuk megjelenhet, és technikai segítséget nyújtanának ezek összegyújtésében, esetleges digitalizációjában, rendszerezésében.

Úgy véljük, a könyvtár szerepével tökéletesen összeegyeztethető lenne, ha felvállalná a személyes digitális hagyatékok kezelését. Az IFLA nyilatkozata a könyvtárakról és fejlődésről ${ }^{8}$ kimondja, hogy „Támogathatják a formális, az informális és az egész életen át tartó tanulást, a népi emlékezet és az öslakos tudás, valamint a nemzeti kulturális és tudományos örökeség megörzését.” („They can support formal, informal and lifelong learning, the preservation of folk memories, traditional and indigenous knowledge, and the national cultural and scientific heritage.") 


\section{NAGY ANDOR}

A digitális adattárolásnak az a nagy előnye, hogy nem kell papírt használnunk az információk rögzítéséhez, ezáltal azok sokkal könnyebben továbbíthatók, másolhatók és szerkeszthetők. Az emberek mindennapjaikban egyre kevesebbszer találkoznak papírral, és eljöhet majd az az idő is, amikor egyáltalán nem használunk papírt, minden információt bitek formájában fogunk tárolni. Ez a jelenség azonban magával hozhatja az ún. „digitális sötét kort.”

\section{A digitális sötét kor}

Az élet egyre több területe digitalizálódik, és a legtöbb esetben ez hasznos és kívánatos jelenség, hiszen a mindennapi életünket könnyíti meg és a digitalizálás segít megőrizni olyan analóg tárgyi emlékeket, amelyek egyébként elvesznének vagy sérülnének. Az elmúlt években számos olyan adatbázis jött létre, amelyek digitalizált dokumentumokat tartalmaznak, és ezek az adatbázisok nemcsak azért bírnak jelentős értékkel, mert hozzájárulnak a régi fényképek, videók, szövegek és más tárgyi emlékek hosszú távú megôrzéséhez (ha erről megfelelő módon gondoskodtak), hanem azért is, mert ezek az anyagok azokhoz is eljuthatnak, akik egyébként soha nem találkoznának velük. Ennek egy jó példája a Fôvárosi Szabó Ervin Könyvtár Hullámfürdố záróra elött címú gyújteménye, amely olyan fotókat tartalmaz, amelyeket Pusz̧tai Sándor készített a Gellért Fürdőben, és történelmi szempontból is rendkívül értékesek. A gyüjtemény és annak webes felülete Fodor János vezetésével szakértők és az ELTE Könyvtár- és Információtudományi Intézet hallgatóinak bevonásával jött létre. ${ }^{9}$ Mindazonáltal, a digitalizálódás és digitalizálás történelmi távlatban komoly veszélyeket rejt magában.

A történelemben azokat az időket nevezik sötét kornak, amelyekrôl nagyon kevés olyan anyag maradt ránk, amely mesélni tud az adott korszakról. Vint Cerf, az internet egyik alapító atyja szerint a digitális sötét kor azért fenyeget, mert kevés megbízható adattárolási megoldást ismerünk, miközben nagyon sokféle számítógépes fájlformátum van használatban, ezek megjelenítéséhez pedig sokféle szoftverre van szükség. A fizikai adathordozókon való redundáns adattárolás, illetve a felhőtechnológia használata csak ideiglenes megoldást jelent, hiszen az adathordozók (pl. merevlemez, szilárdtest-meghajtó, optikai adattárolók stb.) élettartama véges, a felhőszervereket pedig olyan kereskedelmi technológiai nagyvállalatok üzemeltetik, amelyek idővel megszűnhetnek. Vint Cerf szerint, ha nem találunk megoldást, a XXI. század történelmi távlatban információs feketelyuk lehet. ${ }^{10}$

A „digital dark age” legkorábbi említését az IFLA 63., Koppenhágában megtartott világkonferenciája egyik előadásában ${ }^{11}$ találtuk meg. Az előadó ezzel a kijelentésével megelőzte a korát, mivel az előadás elhangzásakor, 1997-ben mindössze hatéves volt a világháló (World Wide Web = WWW), így akkor még nem volt előre látható, hogy a jövőben milyen méreteket fog ölteni a digitalizáció. 


\section{Zárszóó}

A könyvtárnak megvan a lehetősége, hogy aktív szereplőjévé váljon azoknak a törekvéseknek, amelyek azt hivatottak megakadályozni, hogy a XXI. század történelmi távlatban információs feketelyukká váljon. Tanulmányunkban több digitálishagyaték-kezelő szolgáltatást is bemutattunk, és arra is kitértünk, hogy a legtöbb szolgáltatás nem nyújt garanciát arra, hogy egy életen át megőrzi a szerverein eltárolt digitális hagyatékokat. Ezeket ráadásul nemcsak megőrizni kell, hanem biztosítani, hogy a technológia fejlődésével párhuzamosan a régi fájlformátumok is használhatók maradjanak (rendszeres fájlkonverzióval). A könyvtárak által vállalt személyes digitálishagyaték-kezelést térítéses szolgáltatás formájában tudjuk elképzelni, mivel így nemcsak fenntarthatóvá válna a szolgáltatás üzemeltetése, de bevételi forrást is jelentene a könyvtárak számára. A weben sok olyan térítéses digitálishagyaték-kezelő szolgáltatás múködik, amelyek hátteréről alig tudunk valamit, mégis évek óta üzemelnek, ami komoly használói igényt jelez. A nemzeti könyvtárak általában olyan nagyméretű, nagy múltú szervezetek, amelyek képesek lennének sokkal erősebb garanciákat nyújtani, és ennek folytán talán a felhasználói bizalom is nagyobb lenne feléjük, mint a komoly szervezeti háttér nélküli és garanciát nem biztosító szolgáltatások irányába.

A hosszú távú biztonságos adattárolás mikéntjét nem a könyvtáraknak kell kitalálniuk, mivel az évtizedek alatt kiforrott szabványok részletesen leírják, hogy miként kell felépíteni egy digitális adattárat.

\section{Jegyzetek és irodalom}

1. HAWKINS, Donald T.: Personal archiving: preserving our digital heritage. Medford, Information Today, 2013.

2. MARSHALL, Brianna H.: The complete guide to personal digital archiving. Illinois, American Library Association, 2017.

3. KOWALCZYK, Stacy T.: Digital curation for libraries and archives. Exeter, Libraries Unlimited, 2018.

4. Research Libraries Group: Trusted digital repositories: attributes and responsibilities. Mountain View, RLG, 2002. Forrás: https://www.oclc.org/content/dam/research/activities/ trustedrep/repositories.pdf [2019. január 4.]

5. Centre of Research Libraries: Ten principles. 2007. Forrás: https://www.crl.edu/archivingpreservation/digital-archives/metrics-assessing-and-certifying/core-re [2019. január 2.]

6. National Digital Information Infrastructure and Preservation Program: about the program. Forrás: http:/ / fortune.com/2011/03/01/google-goes-to-the-tape-to-get-lost-emails-back [2019. január 11.]

7. ISO 16363:2012: Space data and information transfer systems - Audit and certification of trustworthy digital repositories. Forrás: https://www.iso.org/standard/56510.html [2019. január 5.] 


\section{NAGY ANDOR}

8. International Federation of Library Associations and Institutions: IFLA statement on libraries and development (August 2013). Forrás: https://www.ifla.org/publications/iflastatement-on-libraries-and-development [2019. január 5.]

9. FODOR János - KISZL Péter: Developing digital collections: a training model of digital humanities web projects in library and information science education. = Informatio et Scientia. Information Science Research, Vol. 1. No. 1. 2018. 17-18. p. Forrás: https://wow. umcs.pl/czasopisma/controller/Default/module/Ejournals/action/downloadContent/ $\mathrm{cid} / 81$ [2019. január 14.]

10. GHOSH, Pallab: Google's Vint Cerf warns of ,digital Dark Age'. = BBC News, 2015. 02. 13. Forrás: https://www.bbc.com/news/science-environment-31450389 [2019. január 7.$]$

11. KUNY, Terry: The digital dark ages?: challenges in the preservation of electronic information. = International Preservation News, No. 17. 1998. 8-13. p. Forrás: https://archive.ifla.org/ IV/ifla63/63kuny1.pdf [2019. január 9.]

Nagy Andor - informatikus könyvtáros és informatikai rendszergazda végzettségú doktorandusz hallgató, az Országos Széchényi Könyvtár Könyvtári Intézete Kutatási és Elemző Osztályának fóállású munkatársa, a Pécsi Tudományegyetem Bölcsészettudományi Karának tanársegéd oktatója. Az ELTE BTK Irodalomtudományi Doktori Iskola Könyvtártudományi Doktori Programjának doktorandusz hallgatója. Kutatási területei: DRM-technológiák, automatizált tartalomelemzés, fenntartható digitalizálás. ORCID: 0000-0002-9404-0091 